\title{
Imperatives of a Wellbeing Economy in Nigeria
}

\author{
Fidelis Allen, PhD \\ Department of Political and Administrative Studies, University of Port Harcourt Choba, Port Harcourt, \\ Nigeria.
}

*Corresponding Author:Fidelis Allen, PhD (UKZN), Department of Political and Administrative Studies, University of Port Harcourt Choba, Port Harcourt, Nigeria, Email:fidelis.allen@uniport.edu.ng.

\begin{abstract}
The wellbeing economy paradigm has implications for socio-economic change in countries like Nigeria and others easily linked to the irony of natural resource curse and blessing. Stories of violent conflict, poverty and bad governance are widespread in these countries. Within this context, and based on participant observation of two major meetings of members of We-Africa Network in 2015 and 2017, this article reflects on the imperatives of an emerging paradigm (wellbeing economy), capable of influencing policy relevant development discourse in Africa, with particular reference to Nigeria. It however warns against the risk of failing systems repackaging themselves (capitalist modes of prosperity) in the guise of this proposal, as always, and in all ages, capitalism must devise ways of surviving or demonstrating resilience in the face of scorching challenges. Nigeria's more than fifty-year-old oil industry has a lot of lessons to provide in any discussion of justifications for alternative development models. The wellbeing economy framework will mean rejigging the country's existing economic, social and political foundations, not only to take from the political and economic class power and domicile in the people, but also to make petroleum less visible as driver of the economy. In its place, a thriving manufacturing and service sector as well as technological advancement, along with a revived agricultural system that meets food security needs, will be less a threat to prospects of a wellbeing economy in which economic activities and ecological systems achieve a good balance.
\end{abstract}

Keywords:Imperatives, Wellbeing, Economy, Nigeria.

\section{INTRODUCTION}

The Wellbeing Economy is an emerging paradigm with useful assumptions for framing economic, environmental, social and political goals. Finding the route to reaching these goals is part of what advocates are seriously concerned about. They are mainly concerned about how to improve the wellbeing of people and ecosystems. This certainly did not make much sense to me prior to November 2015. The director of the Centre for the Study of Governance Innovation at University of Pretoria, South Africa, Professor Lorenzo Fioramonti, had invited me to participate in an initial meeting of would-be members of the Wellbeing Economy Africa Network (WE-Africa Network, for short). It was illuminating. Between that time and November 2017, Lorenzo, convener of the wellbeing economy conferences and main driver of the dream of a wellbeing economy movement in Africa, launched a new book, Wellbeing Economy, Success in a World without Growth. ${ }^{l}$ Apart from the intellectual engagement with issues of conceptualization and indicative arguments about what the concept means, this book echoes a tacit call for theory and praxis, in the aspirations for change across Africa. The political economy background of the book presents good reading of the African situation. The quick message was, as now, an arrival of a paradigm, which is not necessarily new in postcolonial engagement with development discourses and critique of global capitalism. The wellbeing economy framework is intended to guide development thinking and action. It is about desire for change in the way countries organize their economies, away from the growth mantra. Clearly, the framework is a pointer to an effort by advocates seeking a paradigmatic shift, strong enough to serve as conceptual and analytical tool for activism and change. Within the period, at the instance of Lorenzo's leadership, a Wellbeing Economy Lab was created, with innovation as a key goal. This has

\footnotetext{
${ }^{1}$ Lorenzo Fioramonti. 2017. Wellbeing Economy, Success in a World Without Growth, Johannesburg: Pan Macmillan
} 
been more or less targeted at finding best ways for reaching the wellbeing economy in Africa. At the time of writing, the 2017 Wellbeing Economy Festival, which started on 27 November at the CSIR International Convention in Pretoria, had just ended (on 30th day of the month). It was a great time, for wholesale amplification of the meaning, content and indicators of the concept, through conversations and insightful stories. Below was my contribution to the meaning of wellbeing economy, on request by one of the facilitators to members of the network on www.slido.com:

It means social, economic and political life processes that give due attention to human and nonhuman welfare. This is all encompassing, including commitment on the part of individuals to achieving a world system that takes away oppression of human and non-human elements of the earth ${ }^{2}$

The state of human and non-human elements of the economy, which social, economic, and political processes must be sensitive to, is a critical pointer to the fact things should not be business-as-usual. The paradigm suggests claim and injection of a new approach into the development debate, not only in Africa, but in all economies across the world, currently reeling with effects that make society ever more unequal. It has to be seen in part, as another conceptual tool for exploring the shortcomings of current growth models. The growth models have mainly failed to bring meaningful change to lives of people and their environment. To be sure, despite regular statements of growth figures that point to prosperity in some countries in Africa, when it comes to quality life of citizens, the continent has remained basically on the margins. The truth is, the global economic system glorifies growth in disregard of impact on living conditions of people (Lorenzo 2017). Worse, is the near incidental position that the health of ecosystems occupies within the growth economy. Number or quantity, which the growth economic models promote, is highly deceptive and blind to conditions of the majority of citizens of the world. Even more so is when we look at it in relation to inequality. What has happened is that, while many people have become poorer and ecosystems have been injured beyond easy remedy, countries have glowed with numbers that portray prosperity or wellbeing. Measuring prosperity with numbers that basically dismiss social and environmental costs, and deaths that arise from conflicts in many situations of natural resource driven growth, are critical issues.

\section{Nigeria SituAtion}

A vision of a wellbeing economy in Nigeria has to be seen in respect of expectations across the country. For the great majority of citizens, it should suggest a paradigm shift that gives attention to the core of their humanity, for which current models have despised with impunity. For example, more than 75 percent of Nigeria's 180 million people, as of today, are without electricity. But government has consistently injected public funds into finding ways out of this problem. Meanwhile, government (at the federal and state levels) has consistently budgeted huge amount of money, annually for tackling the problem of power without given due attention to renewable energy sources, where the answer lies.

The growth economy, characteristically, does not seem to rest on any long term social benefits if an immediate prospect for profit is not in sight. This is rational with the free market system. However, it must fit with social sensibilities. No matter how capital tries to give a human face to its organization of economic activities, the results, mainly have been anti-people (majority of the population) in the developing world. This means inequality. Whether in Nigeria, South Africa, or Ghana, outcome of economic processes, based on the free market system, tend to inhibition of real progress for the wide majority. Instead those who own capital and command cheap labour, smile to their banks.

In the first place, internationalization of capital, in the old and new ages, functions within specific interest of profit-making, via exploitation of labour and natural resources. Classical economic theorists like Adam Smith, argue that the invisible hand has a social role to play in the prosperity of society. As believable as this may sound, reality has shown that for the developing countries of Africa, where international capital has continued to search for opportunities, it has to be seen from the point of view of exploitation of labour and natural resources, than from any properly advertised wisdom of the free market system.

2This was my own contribution to a question on the meaning of wellbeing economy, asked at www.salido.com to participants in the Wellbeing Economy Festival of 2017. 
Social transformation, defined in terms of wellbeing of citizens and environment, has been outside the goal of business. The situation differs on the basis of regulations and their functionality in different countries. The global economy and behaviour of capital, especially in developing countries of Africa, have failed to handle challenges in these countries. A few countries in Asia may have reasons to argue transitions away from the problems Africa has been through. Stories continue to point to shrinking value of capital, in the face of increasing social and environmental costs. In many of these countries, champions of industry and the local political class have dominated the space that otherwise would have been an area of influence by the vast majority of citizens in the public interest. Growth in the number of economically and socially deprived persons amidst intimidating growth statistics, often mentioned in both print and electronic media, has attracted scathing condemnation and ridiculing. This has been more so for capitalism. A few African countries come very close to a glory based on improving growth statistics. In reality, these countries continue to face economies that deny citizens access to basic social amenities. Consequently, the continent has remained a victim of crisis that easily links with a broken capitalist system. To some extent, intense violent struggle for power in the internal politics of these countries is part of the result of this broken capitalist regime. Now, more than ever, Africa's social and economic crises have pushed the migratory tendencies of its helpless peoples to dangerous limits. They migrate inspite of the dangers ahead. Governance and character of African leaders as collaborators with corporations in search of natural resources, have failed to create room to absorb victims of the free market order. These are the class of people on the run to continents where capitalism seem to have devised modest ways of providing for its victims. But, this is a systemic problem. The global free market system is penetrative, with principles that have a global agenda.

Possibilities of change are suggested in the wellbeing economy, via a different form of organizing production and services. In the case of Nigeria, it has the potential of ridiculing her many years of excruciating appetite for economic growth through an environmentally destructive extractive sector. In addition, it suggests a shift away from a system that sees environment and socio-economic wellbeing as incidental. This contradiction, speaks clearly about failure of a system that cares little about the people and environment and therefore sees those as secondary in the organization of economy. How different will the wellbeing economy be? Will people and environment be priority? What is the political economy and character of policy analysis of that economy? Is the wellbeing economy already being seen in multilateral, bilateral and national policy frameworks? Does it carry any ideological content capable of either promoting capitalism or alternatives in the long run?

The oil industry in Nigeria is more than fifty years old. Previously, local communities lived simple lives, based on access to other resources of the environment. Between 1956, when oil was first discovered in commercial quantity, and now, Nigeria has earned more than $\$ 600$ billion from the sale of the commodity. To be sure, Nigeria has depended on the industry for the bulk of her national income and foreign exchange. Despite fluctuating product price at the global market, huge financial wealth from oil and gas and dependence of the country on the product, for economic planning, has had effects on politics and ethnic-relations in the country. Oil is at the centre of politics, serving as key motivator for growing violence among contestants for political offices. It is simply about struggle for control of the oil money. The worse has to be seen in the environmental woes that have befallen communities in the Niger Delta, where the oil is mainly extracted.

Clean up of pollution caused by regular oil spill, gas flaring and improper waste disposal remains a key sign of lack of sensitivity to the wellbeing of communities. Even with the late coming of laws and policies, for the regulation of activities of companies in the sector (oil and gas) for which naturally the environment and peoples' wellbeing should have been touched positively, communities in the Niger Delta remain a case study of how not to expect natural resource- driven growth contribute to the wellbeing of people and their environment.

Years of research and analysis on issues in the Niger Delta region of Nigeria, have shown that in this case, wellbeing, in part, has to be located in the health of communities, when it comes to access to other resources of the environment and impact of oil and gas on socio-economic life of the people. As things stand, when eventually oil is depleted, communities would have also depleted their chances of having a next generation of people with hope for an environment that is well and sound. 


\section{Implications For Politics, Policy And Analysis}

The wellbeing economy proposition has implications for politics, policy and analysis, all of which are critical for reaching the goal. First, it will privilege a different kind of change through political and policy processes that privilege citizens' preferences. Change may be expected in terms of quantity and quality but not on the basis of existing unethical imbalance. Focus on quantity is inadequate in this sense.

A proper sense of involvement of citizens at family, community, village, and political constituency fronts in development processes, will mean taking away laws that have elements of deprivation of political rights of ordinary people. Note that this will equally mean strengthening political institutions to play more democratic roles, as centres for the projection of citizen choices. This suggests that the politics of the wellbeing economy has to be democratic. The reality of such democratic effect will be seen in political process and outcomes that reflect citizen choices. This will not be synonymous with the welfare economy which capitalism runs. Existing culture where few powerful politicians, using mainly unconventional means of fear and insecurity to keep majority of qualified voters out of view during elections, as well as near insignificance of citizens in post-election governance processes, makes politics unable to achieve wellbeing for the people. This happens at the local, sub-national and national fronts. If politics is about exercise of power in the interest of citizens, the people themselves must be seen to be meaningfully involved in it. Their involvement must transcend election seasons, to include active roles in the entire life span of an existing regime, in relation to public decisions that touch on the very wellbeing of people. The politics of the wellbeing economy further means processes that bring into focus conventional and extra-democratic opportunities of non-violent engagement with political and policy actors by citizens. It means political parities and politicians can even see the wellbeing economy. Therefore, they want to fight practices such as corporate unresponsiveness to environmental commitments by punishing the offence without political considerations that usually consolidate old destructive practices in the name of political survival.

The growth economy in Nigeria is erratic, conflictive and vulnerable to violence. The crisis in the delta is closely linked to the oil and gas economy. The 1990s saw the emergence of armed groups, struggling for resource control. Their grievances have continued to point to environmental problems and failure of government at the federal level to deliver economic and social infrastructure in the region. Meanwhile a strong perception of the country being sustained financially from oil derived from the region is fueling anger. In this case, it is easy to think of the political arrangement, as one in which the three tiers of government are mainly funded with oil money. Their near total reliance on a monthly distribution of money from a federation account for income has implications for the character of these governments.

An aspect of manifestation of traditional notions of resource curse is visible in Nigeria. The risk faced when price turn negative on the country, such as reduction in foreign exchange and national income. When political leaders look less at alternative to the large extractive economy, the danger of losing or failing to explore the advantage of creativity and resourcefulness can easily be completely sacrificed. Even the sphere of agriculture, which previously, was a delight to citizens, and main economic area that served both nutrition and income needs of people, has become a footnote. That means, oil money takes precedence in matters and calculations of the political class. It also means that analysis of the situation, and visions of the desired society with the wellbeing of people and ecosystems, must be based on different indicators. Analysts and researchers must see this as key in any assessment of how to reach the future with the right lenses.

\section{Avoiding THE RISK Of REPACKAgING}

The underlying sense in any discussion of alternative economic models in Africa should not be that of giving the free market system an undue strength. Neither should it be about repackaging or rebranding the failed growth model. Yet this seems a daunting risk or threat, worth avoiding. Every critique of the growth economy suggests a need for neutralizing capitalism and its negative effects on society. By no means, is this a suggestion of socialism or communism as alternatives. What it means is that the wellbeing economy is not any of both ideological corridors. But it is not free from practical multipart ideas that inform the kind of change that differs from what the world has seen with typical free market economies. What needs to be carefully avoided is using large character of the free market system to define the wellbeing economy. The tendency is high. Already, even within the We-Africa 
Network, clear thoughts are still shaky with many coming from the background of years of exploitative business practices. There is no genuine peace lover who sees the gun and other weapons of destruction, as the main instruments of achieving peace. First and foremost, the peacemaker has to be seen to be peaceful in his or her approach to managing conflict.

Demonstration of political will, to change from environmentally destructive big business, politics and inter and intra-community relations is required. In the case of the Niger Delta, worrisome emergence of an illegal oil economy that further endanger the environment and destiny of communities, has to be addressed from the perspective of wellbeing. This will mean community actions that elevate community and environmental health. Community interest and health have to be seen as superior to any short-term material gratification from the destruction of pipelines. Those involved in breaking pipes for the purpose of sucking away crude oil, either for direct sales to waiting ocean-going vessels nautical miles away from the shore, or for small-scale local production for the local market, have to be seen as victims of the capitalist system. For the government, it will mean cleaning up all oil-polluted places in the Niger Delta, dealing with the issue of corruption more courageously and dispassionately with the country at heart. For the oil companies, it will mean more transparent, accountable and ethically driven business practices.

The wellbeing economy will not be a one-size-fits-all. Some would actually say, it is not rocket science. In my view, the route to the wellbeing economy is as much a process, that may be complex. Context is therefore crucial. History, culture and experience of people and communities with economic activities, livelihoods and ecosystems are crucial elements. The principles have universal applications, but every society needs to be seen as unique in some or many ways, of which considerations have to be sufficiently given.

The reason capitalism has survived several centuries, is in part due to its ability to repackage itself when faced with challenges. The global financial crisis, of 2008, which spilled threats, also provided an opportunity for capitalism to re-emerge with mechanisms for dealing with the threats. When inequality turns out to be a factor in resentment and pressure against those in positions of power, capital becomes the trusted ally, by furnishing taxes used in providing welfare programs capable of dousing dangerous uprising against the economic system. Europe remains a good example. Africa has not been as lucky, as capital has been ferocious in the last century. The era of natural resource development of which capital has played a key role, is rather politically authoritarian. Incompatibility of resource-rich countries with democracy follows particular trajectories. The risk of bad governance is well noted in a growing body of literature. Surprisingly, the wellbeing economy, in relation to the oil and gas growth strategy, will mean adopting a non-oil strategy. It will mean communities in the Niger Delta, currently awash with demands for more financial resources and infrastructure will be disappointed for the need to make oil and gas less important for development. What will matter in the short and longer term is addressing the problem of ecological disaster caused by extractive activities. This too, will have a surmountable problem of reluctance of companies and the federal government, to meet their obligations of ensuring environmental sustainability, as expected in relevant regulatory policies. The critical point in all of this is the need for large-scale reforms in governance of the economy. As earlier noted, this will require making the oil dependent economy less so for its many problems. That way, the economy may shrink in the strict sense of an oil and gas growth statistics, in terms of gross domestic product. The shrinking will be short term, giving way to a long-term benefit which can come from expected change in people and environment friendly alternative service and productive systems. Let us assume that Nigeria does not have oil and gas at all.

\section{Pathway}

Some may have already seen this new paradigm, manifesting in many visions at the global fronts. Interestingly, this was suggested in the conversations at the 2017 Wellbeing Economy Festival in Pretoria. For example, current Sustainable Development Goals of the United Nations was easily pointed out as an issue relating theoretically to desired direction for the wellbeing of countries and their peoples. In a similar vein, some countries have had beautiful development plans that suggest a strong desire for the wellbeing of these countries and their people. The question of achieving this economy from the perspective of advocates and emerging indicators, of which the people and ecosystems are key, requires drastic change in economic models. This does not have to be realized through violent confrontations, or what traditional political science would propose as revolutions. 
Already, growing complex relationships in society and economic hardship faced by different groups, have made the idea of the state wielding a monopoly of violence obsolete. A political process approach in which institutions of governance are actively engaged in the discourse of the new development paradigm, from a movement-oriented collective and superior point of view, will be the necessary first step. This will mean placing the paradigm on the political agenda, as a basis for proposing it on the policy agenda. All of this requires regular analysis and advocacy.

The other route is education. As popularly said, no nation can rise above its educational system. Members of the We-Africa Network have a huge role to play in making the proposal enter the curriculaof study in educational institutions. Thinking about development and the right way to go, will depend on how the younger generation are being carried along. In my view, the educational system is a good terrain. However, official inclusion of studies in wellbeing economy in school curricula, may take fairly long to achieve, if the advocacy component is weak. In that case, engaging key political figures will be crucial as well. Seeking opportunities for collective and individual engagement with policy makers and administrators in the education sector is important.

Note the need for change in energy policy development. The Nigeria case, where oil is the basis of energy policy, requires reform. Since 2012 the executive and the legislature at the federal level have been working to enact a new petroleum law to govern the sector. The missing link in the bill, which has now been broken into four parts, to be passed independently or separately, is the subsidiary position environment occupies. Host communities to the oil companies are not visible in the bill, as actors deserving participation, both in the business and in the policy making process. A host community development bill component seems already failing to give host communities adequate opportunity to have a say in how the industry operates.

Oil companies have a wellbeing role to play as well. This will involve an overall review and change in mental view of the political economy of Nigeria to reflect the new expectations of better life for everyone. Corporate profit, power, politics and management of environment, must fit with a new vision of achieving the wellbeing economy, in which violation of environmental and human rights of people must be seen to have become a thing of the past. In some cases, reparations or compensations for reducing the value of humanity and environment will be suggested, for the intense environmental and social costs incurred and yet unaccounted in growth statistics. The real costs are up until now not known. Oil companies have to be responsible for the financial compensation of these costs. That will help towards the wellbeing of those already at the margins of life because of the negative impact of oil and gas pollution.

\section{CONClusion}

The wellbeing economy paradigm has implications for social change in countries like Nigeria and others, known for natural resource curse and blessing. This article has explained the wellbeing economy framework as a discursive category with qualities capable of informing change in economic systems of countries. Likelihood of economic models patterned along the philosophy behind the wellbeing economy frame, supporting legitimate aspirations of citizens for wellbeing, while discouraging dominance of existing economic models in which the invisible hand of the free market has had an overarching influence is suggested. Without necessarily highlighting the operations of the invisible hand, it notes the erratic nature of the growth economic model, and its encouragement of inequality. Besides, this model is insensitive to the needs of ecosystems, upon which humanity relies for many other natural resources, such as rivers, forests and so on. Nigeria's more than fifty-year-old oil industry has a lot of lessons to give in discussions of alternative models. Adopting the wellbeing economic framework will mean so much, in terms of rearranging prevailing economic, social and political foundations, to make oil and gas less visible, as drivers of the economy. The oil, in this case, will need to become a secondary commodity of national importance. Instead, manufacturing of finished goods, along with a revived agricultural system, are to be seen as less threatening to the prospect of the wellbeing economy, in which economic activities and ecological systems have to be reconciled. 


\section{AUTHORS' BIOGRAPHY}

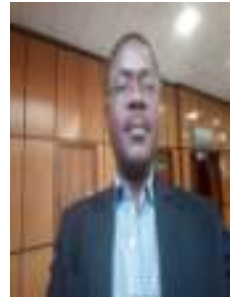

Fidelis Allen is Associate Professor of Politics of Development in the Department of Political and Administrative Studies, University of Port Harcourt, Nigeria. At present, he is serving a second term as acting director of the Centre for Conflict and Gender Studies of this university. Allen is a member of We-Africa Network and head of the Rivers State Conflict Management Alliance. His publications have appeared in reputable journals, edited books and so on, including the International Encyclopedia of Political Science.

Citation:Fidelis Allen, "Imperatives of a Wellbeing Economy in Nigeria" International Journal of Humanities Social Sciences and Education (IJHSSE), vol 5, no. 1, 2018, pp. 16-22. doi: http://dx.doi.org/10.20431/2349-0381.0501004.

Copyright: (1) 2018 Authors. This is an open-access article distributed under the terms of the Creative Commons Attribution License, which permits unrestricted use, distribution, and reproduction in any medium, provided the original author and source are credited. 